Jan Paweł II. Posługa myślenia, t. 2, red. ks. B. Kastelik, A. Krupka, ks. R. Woźniak, Kraków 2015, s. 213-224

(Studia nad Myślą Jana Pawła II, 17).

DOI: http://dx.doi.org/10.15633/9788374384933.12

Vitali Siarko SchP

\title{
JAN PAWEŁ II O MĘCZENNIKACH
}

„Świadectwo męczeńskie tych, którzy za wiarę i chrześcijańskie zasady życia przyjęli cierpienie i męki oraz odważnie ponieśli śmierć, od początku, przez całe wieki dodawało Kościołowi duchowej siły i mocy"1 - pisał Jan Paweł II w liście apostolskim Rutilans agmen [dalej: RA].

Świadomość niezastąpionej roli, jaką odgrywają w Kościele męczennicy, kierowała Janem Pawłem II, którego pontyfikat stał się czasem nadzwyczajnego wzrostu liczby świętych oraz błogosławionych Kościoła. Męczennicy zajmują znaczące miejsce wśród 1338 beatyfikowanych i 482 kanonizowanych przez papieża osób. W gronie tych, którzy zostali wyniesieni podczas pontyfikatu Jana Pawła II na ołtarze, znajduje się 1031 błogosławionych i 402 świętych męczenników ${ }^{2}$. Ich beatyfikacje oraz kanonizacje najczęściej były zbiorowe ${ }^{3}$. Na szczególną uwagę zasługuje fakt, że wszystkim beatyfikacjom oraz kanonizacjom Jan Paweł II przewodniczył osobiście.

Doktryna papieska na temat męczenników zawiera się w całym nauczaniu Jana Pawła II. W sposób szczególny wybrzmiewa ona jednak w beatyfikacyjnych i kanonizacyjnych homiliach, wygłoszonych na cześć męczenników podczas uroczystości wyniesienia ich do chwały ołtarzy.

$1 \quad$ RA 1.

2 Zob. S. Karczewski, Jan Paweł II. Encyklopedia pontyfikatu 1978-2005, Radom 2005, s. 445-491; por. także: J. Poniewierski, Pontyfikat 1978-2005, Kraków 2005, s. 471-486; Canonizzazioni del santo Padre Giovanni Paolo II, http://www.vatican.va/news_services/liturgy/saints/ ELENCO_SANTI_GPII_ok.htm [2.6.2007]; Beatificazioni del santo Padre Giovanni Paolo II, http://www.vatican.va/news_services/liturgy/saint s/ELENCO_BEATI_GPII.htm [2.6.2007]; K. Więcek, Wkład polskich kanonistów do nauki prawa kanonizacyjnego, Lublin 2008, s. 74.

3 Zob. L. Flisikowski, Beatyfikacje i kanonizacje dokonane przez Jana Pawła II, „L'Osservatore Romano" (wyd. pol.) 13 (1992) nr 5, s. 57-58. 
Niniejsze opracowanie ma na celu omówienie beatyfikacji oraz kanonizacji męczenników, dokonanych przez Jana Pawła II oraz przypomnienie - w oparciu o wygłoszone przez Papieża homilie - głównych myśli jego nauczania o męczennikach.

W gronie świadków wiary, wyniesionych do chwały ołtarzy przez Jana Pawła II, męczennicy grupowi stanowią większość, dlatego zostaną oni przedstawieni w pierwszej kolejności. Po nich omówieni zostaną męczennicy indywidualni.

\section{Męczennicy grupowi}

W homilii wygłoszonej w 1999 roku w Bydgoszczy Jan Paweł II powiedział: „W ciągu dwudziestu lat pontyfikatu wyniosłem do chwały ołtarzy wielkie grupy męczenników: japońskich, francuskich, wietnamskich, hiszpańskich, meksykańskich. A iluż ich było w okresie II wojny światowej i w czasie panowania totalitarnego systemu komunistycznego!"

Idąc za myślą papieża i kierując się zarazem chęcią usystematyzowania jego nauczania w sposób jasny oraz dostępny, w tekście przyjęta zostanie taka kolejność omawiania męczenników grupowych, jaką w bydgoskiej homilii zaproponował sam Jan Paweł II.

\subsection{Męczennicy japońscy i wietnamscy}

Pierwszą grupą męczenników, wymienioną w homilii Jana Pawła II, są męczennicy japońscy. Ta grupa świadków wiary połączona zostanie z męczennikami wietnamskimi, ponieważ historie i okoliczności ich śmierci są do siebie podobne. Byli oni albo misjonarzami, którzy przybyli na tereny misyjne, by głosić Ewangelię, albo miejscowymi chrześcijanami, którzy po usłyszeniu Dobrej Nowiny, przyjęli chrzest i oddali swoje życie za wiarę.

\subsubsection{Męczennicy japońscy}

Początek prześladowań chrześcijaństwa w Japonii sięga 1587 roku. Od tego czasu poszczególni władcy wydawali kolejne dekrety, nakazujące misjonarzom

$4 \quad$ Jan Paweł II, Błogosławieni, którzy cierpia prześladowanie dla sprawiedliwości, albowiem do nich należy królestwo niebieskie (Mt 5, 10). Homilia wygłoszona w Bydgoszczy, 07.06.1999, http://www.pielgrzymka.opoka.org.pl/bydgoszcz/przemowienie1.html [29.1.2015], 3. 
opuszczenie kraju, miejscowym chrześcijanom zakazujące natomiast pod karą śmierci wyznawania swojej religii. W XVII wieku Kościół japoński zszedł zupełnie do podziemia. Stał się wspólnotą wierzących pozbawioną kapłanów, ale nie katechistów miejscowych, którzy przejęli rolę dalszego ewangelizowania swoich rodaków. Ich działalność pomogła Kościołowi w Japonii przeżyć okres katakumb, który trwał niemal 200 lat ${ }^{5}$.

W ciągu wieków Kościół wyniósł do chwały ołtarzy wielką liczbę męczenników japońskich. Pierwsza beatyfikacja miała miejsce w 1627 roku. Jan Paweł II kontynuował działalność swoich poprzedników. 18 lutego 1981 roku papież beatyfikował Wawrzyńca Ruiza, ojca rodziny pochodzącego z Manili, oraz 16 towarzyszy ${ }^{6}$. Kolejnej beatyfikacji dwóch japońskich misjonarzy-męczenników papież przewodniczył 23 kwietnia 1989 roku ${ }^{7}$

Błogosławieni męczennicy japońscy zostali wyniesieni do chwały ołtarzy przez Jana Pawła II jako ci, którzy „z odwagą wnieśli swój wkład w głoszenie Ewangelii aż po krańce świata" . Dzięki swojej wytrwałości każdy z japońskich świadków wiary stanął przed Kościołem „Z własnym świadectwem, męczeństwem i miłością, z własną wiarą i konkretnymi dziełami dokonanymi w służbie Kościoła”" Męczennicy z Kraju Kwitnącej Wiśni złożyli swoje świadectwo wiary zarówno wobec Kościoła powszechnego, jak i japońskiego.

W celu uczczenia tego świadectwa 26 lutego 1981 roku Jan Paweł II udał się na Wzgórze w Nagasaki. W miejscu ukrzyżowania oraz śmierci 26 świętych męczenników japońskich wygłosił okolicznościowe przemówienie ${ }^{10}$.

$5 \quad$ Zob. G. Kucharczyk, Męczeństwo w Kraju Kwitnącej Wiśni, http://www.milujcie sie.org.pl/nr/karty_historii_kosciola/meczenstwo_w_kraju_kwitnacej.html [29.1.2015]; por. także T. Wojda, Panie, daj nam doświadczyć nieba, http://storico.radiovaticana.org/pol/ storico/2010-02/360334_okruchy_ewangelii_ii_niedziela_wielkiego_p ostu.html [20.9.2010].

$6 \quad$ Zob. Święci męczennicy Wawrzyniec Ruiz i Towarzysze, http://www.brewiarz.katolik. pl/czytelnia/swieci/09-26b.php3 [28.10.2007].

7 Zob. Ufficio delle celebrazioni liturgiche del sommo pontefice. Beatificazioni del santo Padre Giovanni Paolo II, http://www.vatican.va/news_services/liturgy/saints/ELENCO_ BEATI_GPII.htm [29.1.2015].

${ }_{8} \quad$ Jan Pawel II, I nuovi santi parlano all'Europa, all'Asia, a tutta la Chiesa ed esortano a ravvivare la conscienza missionaria del popolo do Dio. Homilia wygłoszona w Rzymie, 18.10.1987, „Insegnamenti di Giovanni Paolo II” t. 10/3, s. 880.

9 Tenże, Bóg został w nich otoczony chwała. Homilia wygłoszona w Rzymie, 23.04.1989, „L'Osservatore Romano” (wyd. pol.) 10 (1989) nr 4, s. 16.

10 Zob. A. Jackowski, Leksykon pielgrzymek, Kraków 2005, s. 340-341; por. także: Podróż apostolska Jana Pawła II na Daleki Wschód, „L'Osservatore Romano” (wyd. pol.) 2 (1981) nr 2, s. 11-14. 


\subsubsection{Męczennicy wietnamscy}

W 1533 roku wydany został pierwszy dekret zakazujący głoszenia wiary chrześcijańskiej na terenie Wietnamu ${ }^{11}$. Następnie przez około 300 lat Kościół wietnamski doznawał od zmieniających się władców ciągłych prześladowań. Między 1625 a 1886 rokiem dynastie panujące w Wietnamie wydały 53 edykty o prześladowaniach, w wyniku których zgładzono ponad 130 tysięcy wietnamskich chrześcijan. Byli oni aresztowani, torturowani, więzieni, skazywani na banicję, konfiskowano im majątek. Wielu katolików wietnamskich oddało swoje życie w masowych egzekucjach ${ }^{12}$.

Podczas prześladowań wietnamskich zginęło między innymi 117 męczenników, których zbiorowe, następujące po sobie beatyfikacje miały miejsce podczas pontyfikatów: Leona XIII, Piusa X i Piusa XII. 19 czerwca 1988 roku Jan Paweł II dokonał wspólnej kanonizacji 117 męczenników Kościoła wietnamskiego, beatyfikowanych przez swoich poprzedników ${ }^{13}$. W homilii kanonizacyjnej papież wyjaśnił, że na ich przykładzie pragnie „ukazać całemu Kościołowi żywotność i wielkość Kościoła wietnamskiego, jego siłę, cierpliwość, jego zdolność przezwyciężania różnorakich trudności w głoszeniu Chrystusa"14. Słowa Jana Pawła II pozostają aktualne, zwłaszcza, jeśli się uwzględni fakt, że chrześcijanie wietnamscy prześladowani są także w naszych czasach.

\subsection{Męczennicy francuscy}

Rewolucja francuska odsłoniła swoje antychrześcijańskie oblicze, rozpoczynając ucisk katolickich księży i osób zakonnych. Wśród ofiar zgładzonych w czasie trwania rewolucji osoby duchowne stanowią jedną z największych

11 Zob. E. Osiecki, Historia Kościoła katolickiego w Wietnamie, http://www.katolik.pl/ index1.php?st=artykuly \&id=1027 [25.1.2015].

12 Zob. Jubileusz wietnamskich katolików, http://www.radiovaticana.org/pol/Articolo. asp?c=336999 [26.11.2009]; por. także E. Osiecki, Historia Kościoła katolickiego w Wietnamie, art. cyt.

13 Zob. Ufficio delle celebrazioni liturgiche del sommo pontefice. Canonizzazioni del santo Padre Giovanni Paolo II, http://www.vatican.va/news_services/liturgy/saints/ELENCO_SAN TI_GPII.htm [31.1.2015]; zob. także: Święty Ignacy Klemens Delgado, Biskup, Wincenty Le Quang Lien a Pace, kapłan, Dominik Phan Trong (An) Kham, tercjarz i 114 towarzyszy, męczennicy wietnamscy, http://www.dominikanie.pl/old/zakon /swieci-d11.html [12.6.2008]; Święci męczennicy Paweł Mi, Piotr Doung-Lac i Piotr Truat, http://brewiarz.pl/czytelnia/swieci/12-18. php3 [17.12.2007]; A. Kość, Męczennicy Dalekiego Wschodu, „Ethos” 13 (2001) 1-2, s. 209.

14 Jan Paweł II, Sanguis martyrum, semen christianorum. Homilia wygłoszona w Rzymie, 19.06.1988, „L'Osservatore Romano” (wyd. pol.) 9 (1988) 7, s. 30. 
grup $^{15}$. Ataki na chrześcijaństwo przybrały takie rozmiary, że rewolucję francuską słusznie uważa się za krwawe prześladowanie Kościoła ${ }^{16}$.

Jan Paweł II w czasie swojego pontyfikatu wyniósł do chwały ołtarzy 163 męczenników z czasów rewolucji francuskiej, przez co radykalnie powiększyła się ogólna liczba błogosławionych męczenników Kościoła katolickiego. 19 lutego 1984 roku papież dokonał beatyfikacji 99 sług Bożych: Wilhelma Repina oraz jego towarzyszy. Kolejny przykład męczenników rewolucji francuskiej Jan Paweł II ukazał Kościołowi oraz światu 1 października 1995 roku, dokonując beatyfikacji 64 męczenników ${ }^{17}$.

Mówiąc o francuskich świadkach wiary, Jan Paweł II podkreślał ich wierność Kościołowi oraz papieżowi. Tłumaczył: [Męczennicy francuscy] „umarli, ponieważ pragnęli aż do końca dać świadectwo trwałej jedności z Papieżem Piusem VI” ${ }^{18}$.Wszyscy oni „potrafili dać świadectwo wobec swych sędziów i oprawców, i wobec tych, którzy przyglądając się ich męce nie mogli pohamować zdziwienia i odchodząc mówili, że było w tej śmierci coś niezwykłego, coś, do czego w ostatnich chwilach życia może natchnąć tylko religia"19.

Męczennicy francuscy woleli ponieść śmierć męczeńską, niż zdradzić Kościól, sprzeciwić się jego nauczaniu oraz odrzucić autorytet papieża, którego stanowisko dawało im pewność moralną, że postępują właściwie ${ }^{20}$.

15 Zob. G. Kucharczyk, Czerwone karty Kościoła, Dębogóra 2008, s. 64-71; por. także: L. Mezzadri, Rewolucja francuska a Kościót, przekł. E. Łukaszyk, Kraków 2007, s. 117-120; 213-214; B. Kumor, Kościót we Francji w okresie wielkiej rewolucji francuskiej, [w:] tegoż, Historia Kościoła, t. 6, Lublin 1985, s. 189.

16 Zob. M. Urbaniak, Za Boga i Kościół, http://ien.pl/index.php/archives/200 [1.6.2009]; por. także G. Kucharczyk, Czerwone karty Kościoła, dz. cyt., s. 70.

17 Pełny wykaz imion i nazwisk wszystkich męczenników francuskich oraz opisy ich męczeństwa znajdują się w: Ufficio delle celebrazioni liturgiche del sommo pontefice. Beatificazioni del santo Padre Giovanni Paolo II, art. cyt.; por. także: Męczennicy francuscy, „L'Osservatore Romano" (wyd. pol.) 17 (1996) 1, s. 27; S. Karczewski, Jan Paweł II. Encyklopedia pontyfikatu 1978-2005, dz. cyt., s. 216; 466-468; G. Kucharczyk, Czerwone karty Kościoła, dz. cyt., s. 74; tenże, Nienawiść i pogarda, Kraków 2010, s. 26; J. Poniewierski, Pontyfikat, dz. cyt., s. 272; J. Seremak, Miłość ponad wszystko, Marki 2005, s. 58-59.

18 Jan Paweł II, Wyznawali wiarę aż do męczeństwa. Homilia wygłoszona w Rzymie 01.10.1995, „L’Osservatore Romano” (wyd. pol.) 17 (1996) 1, s. 24.

19 Tenże, Musimy prosić o odwage wiary. Homilia wygłoszona w Rzymie 19.02.1984, „L'Osservatore Romano” (wyd. pol.) 5 (1984) 3, s. 14.

20 Zob. J. Lisowki, Koncepcja męczeństwa w praktyce Kongregacji Spraw Kanonizacyjnych, Wrocław-Rzym 1992, s. 159-161. 


\subsection{Męczennicy hiszpańscy}

Stan liczbowy duchownych oraz osób zakonnych, którzy zginęli podczas prześladowań religijnych w Hiszpanii w latach 1931-1936 wygląda następująco: 13 biskupów, 4022 księży diecezjalnych, 95 seminarzystów, 2376 zakonników i 282 zakonnice. Dane co do katolików świeckich są natomiast trudne do ustalenia, ponieważ nie ma obiektywnego kryterium, pozwalającego uznać, kiedy zostali oni zamordowani wyłącznie ze względu na wiarę, a kiedy ich wiara była jedynie jednym $\mathrm{z}$ wielu czynników ${ }^{21}$.

Jan Paweł II podczas swojego pontyfikatu przewodniczył 10 beatyfikacjom oraz 2 kanonizacjom męczenników, wybranych z wielkiej liczby osób zabitych w trakcie wojny domowej w Hiszpanii. W tym gronie znalazło się 471 męczenników, których papież beatyfikował oraz 11 osób, które kanonizował. Wśród nich są przedstawiciele wszystkich stanów Kościoła: 4 biskupów, 43 księży diecezjalnych, 379 osób konsekrowanych i 45 świeckich ${ }^{22}$.

Wyjaśniając podczas jednej z beatyfikacji powód śmierci męczenników hiszpańskich, Jan Paweł II mówił: „Zostali [oni] zamordowani, bo byli chrześcijanami. [...] W tamtych straszliwych latach wielu kapłanów, zakonników, zakonnic i świeckich zostało zabitych tylko dlatego, że byli czynnymi członkami Kościoła. [...] [Męczennicy hiszpańscy] [...] nie byli zamieszani w walki polityczne ani ideologiczne - nie chcieli w nich uczestniczyć. Dobrze o tym

21 Zob. P. Moa, Mity wojny domowej. Hiszpania 1936-1939, tłum. A. Fijałkowska, K. Kacprzak, Warszawa 2007, s. 245; por. także: C. Ryszka, Jan Paweł II Wielki, Częstochowa 2005, s. 557; G. Kucharczyk, Czerwone karty Kościoła, dz. cyt., s. 264; A. Riccardi, Stulecie męczenników: Świadkowie wiary XX wieku, przeł. J. Dembska, Warszawa 2001, s. 371; M. Astrua, I was będa prześladować: męczennicy chrześcijańscy XX wieku, tłum. W. Kapica, Warszawa 2006, s. 57; B. Kumor, Historia Kościoła, t. 8, Lublin 1985, s. 109-110.

22 Zob. Ufficio delle celebrazioni liturgiche del sommo pontefice. Beatificazioni del santo Padre Giovanni Paolo II, art. cyt.; zob. także Ufficio delle celebrazioni liturgiche del sommo pontefice. Canonizzazioni del santo Padre Giovanni Paolo II, art. cyt.; S. Praśkiewicz, Żyz wśród nas, Kraków 2007, s. 12; K. Rajski, Rewolucja francuska i powrót męczenników - ofiar systemów totalitarnych, http://www.opoka.org.pl/biblioteka/T/TS/swieci/swietosckan4_07. html [15.1.2015]. Następcy Jana Pawła II kontynuują rozpoczętą przez niego działalność beatyfikacyjną męczenników hiszpańskich. I tak 28.10.2007, za pontyfikatu Benedykta XVI, w Rzymie miała miejsce beatyfikacja 498 męczenników hiszpańskich. Natomiast 13.10.2013, za pontyfikatu Franciszka, w Tarragonie odbyła się największa w historii Kościoła katolickiego beatyfikacja. Do chwały ołtarzy wyniesionych wówczas zostało 522 męczenników hiszpańskich. Tym sposobem obecnie Kościół ma 1502 męczenników z okresu prześladowań w Hiszpanii. Zob. http://www.persecucionreligiosa.es/ [31.1.2015]; zob. także http://www. beatificacion2013.com/ [31.1.2015]. 
wie wielu z was, którzy jesteście członkami ich rodzin i z radością uczestniczycie w dzisiejszej beatyfikacji. [Męczennicy hiszpańscy] [...] zginęli wyłącznie z przyczyn religijnych" ${ }^{23}$. Dlatego „są oni dla nas przykładem życia zgodnego z wyznawaną prawdą, a zarazem przynoszą zaszczyt szlachetnemu narodowi hiszpańskiemu i Kościołowi”24.

\subsection{Męczennicy meksykańscy}

Między 1924 a 1936 rokiem wielu meksykańskich chrześcijan potwierdziło świadectwo swojej wiary krwią, przelaną podczas prześladowań Kościoła inspirowanych przez masonerię, będącą główną siłą sprawczą rewolucji religijnej $\mathrm{w}$ tym kraju ${ }^{25}$. Wśród tych, którzy zginęli podczas prześladowań w Meksyku, było wielu duchownych. Dzięki swojej nieugiętej postawie wiernego trwania przy Bogu i Kościele przeszli oni przez prześladowania i szykany oraz ponieśli śmierć męczeńską ${ }^{26}$.

Jan Paweł II wyniósł do chwały ołtarzy 25 świętych oraz 2 błogosławionych męczenników będących przedstawicielami Kościoła meksykańskiego. Zostali oni zabici podczas prześladowań mających miejsce na początku XX wieku. Z grona duchownych najbardziej znanym męczennikiem meksykańskim jest błogosławiony ojciec Michał Augustyn Pro, jezuita, beatyfikowany 25 września 1988 roku ${ }^{27}$.

Tłumacząc aktualność beatyfikacji oraz kanonizacji męczenników meksykańskich, Jan Paweł II mówił: „Są [oni] wzorem dla całego Kościoła, a zwłaszcza dla społeczeństwa meksykańskiego. Po bolesnych próbach, jakie Kościół w Meksyku przeszedł w tamtych burzliwych latach, dzisiaj chrześcijanie meksykańscy, umocnieni także świadectwem tych świadków wiary,

${ }^{23}$ Jan Paweł II, Żyli zgodnie z wyznawana wiara. Homilia wygłoszona w Rzymie 11.03.2001, „L’Osservatore Romano” (wyd. pol.) 22 (2001) 5, s. 17.

24 Tamże.

25 Zob. K. Kaczmarski, Cristiada - meksykańska Wandea, http://wydawnictwo.fronda. $\mathrm{pl} / \mathrm{arch} / 15-16 / 037 . h \mathrm{tm}$ [14.7.2009].

26 Zob. F. Gonzalez, 28 męczenników meksykańskich, [w:] Męczennicy XX wieku, red. L. Balter, S. Dusza, A. Piętka, Poznań 2001, s. 86 (Kolekcja Communio, 14); por. także: J. Meyer, Prześladowania religijne w Meksyku, [w:] Męczennicy XX wieku, dz. cyt., s. 71; M. Astrua, I was będa prześladować..., dz. cyt., s. 30.

${ }_{27}$ Zob. Ufficio delle celebrazioni liturgiche del sommo pontefice. Beatificazioni del santo Padre Giovanni Paolo II, art. cyt.; zob. także Ufficio delle celebrazioni liturgiche del sommo pontefice. Canonizzazioni del santo Padre Giovanni Paolo II, art. cyt. 
mogą żyć w pokoju i zgodzie, przynosząc społeczeństwu bogactwo wartości ewangelicznych" ${ }^{28}$.

Papież pragnął, by „[...] przykład nowych świętych, ten dar Kościoła w Meksyku dla Kościoła powszechnego, nakłonił wszystkich wiernych, aby wszelkimi dostępnymi sposobami, a nade wszystko z pomocą łaski Bożej, odważnie i zdecydowanie dążyli do świętości”29. Wynosząc do chwały ołtarzy męczenników meksykańskich, Jan Paweł II chciał wobec całego świata ukazać przede wszystkim ich bohaterską wierność Bogu i Kościołowi.

\subsection{Męczennicy nazizmu}

Wspomnienia II wojny światowej przywodzą na myśl podeptanie prawa Bożego i naturalnego, barbarzyńską walkę z człowiekiem, programowe eksterminacje narodów. Przy użyciu społecznych haseł narodowy socjalizm dążył z premedytacją do całkowitego wyeliminowania chrześcijaństwa. System nazistowski manifestował swoją działalność ateistyczną, wynikającą z nienawiści do Kościoła i religii. Przez to stał się prześladowcą wiary i Kościoła ${ }^{30}$.

Jan Paweł II przewodniczył podczas swojego pontyfikatu 14 beatyfikacjom oraz 2 kanonizacjom męczenników, zamordowanych podczas prześladowań Kościoła w okresie II wojny światowej, uważanej za jedną „Z najbardziej niszczycielskich i nieludzkich tragedii w naszych dziejach"31. Papież ogłosił błogosławionymi 141 męczenników, świętymi natomiast - 2 świadków, którzy przelali swoją krew za wiarę. Wśród męczenników II wojny światowej, wyniesionych do chwały ołtarzy przez Jana Pawła II, większość - bo aż 123 osoby - to Polacy. Najbardziej znani polscy święci męczennicy nazizmu to: Maksymilian Maria Kolbe i Edyta Stein ${ }^{32}$.

${ }^{28}$ Jan Paweł II, W życiowych próbach wspomagała ich moc wiary i nadziei. Homilia wygłoszona w Rzymie 21.05.2000 „L’Osservatore Romano” (wyd. pol.) 21 (2000) 10, s. 32-33.

29 Tamże, s. 34.

30 Zob. J. Lisowski, Koncepcja męczeństwa w praktyce Kongregacji Spraw Kanonizacyjnych, dz. cyt., s. 71-73; por. także T. Kaczmarek, Nazizm hitlerowski jako „prześladowca wiary”, „Ateneum Kapłańskie” 92 (2000) 548, s. 29.

${ }_{31}$ Jan Paweł II, List apostolski Tu mas mis au tréfonds z okazji pięćdziesiątej rocznicy wybuchu II wojny światowej, 1.

32 Zob. Ufficio delle celebrazioni liturgiche del sommo pontefice. Beatificazioni del santo Padre Giovanni Paolo II, art. cyt.; zob. także: Ufficio delle celebrazioni liturgiche del sommo pontefice. Canonizzazioni del santo Padre Giovanni Paolo II, art. cyt.; Z. Podlejski, Sól ziemi i światłość świata, t. 7, Kraków 2004, s. 233-271. 
Beatyfikacje i kanonizacje męczenników II wojny światowej były częścią wspomnień Karola Wojtyły o trudnym okresie wojennym, którego sam stał się świadkiem. W książce Dar i tajemnica papież dzielił się swoją refleksją nad wydarzeniami własnego życia z okresu II wojny światowej. Pisał: „Otóż $\mathrm{w}$ tym wielkim i straszliwym theatrum wiele zostało mi oszczędzone. Przecież każdego dnia mogłem zostać wzięty z ulicy, z kamieniołomu czy z fabryki i wywieziony do obozu. Nieraz nawet zapytywałem samego siebie: tylu moich rówieśników ginęło, a dlaczego nie ja? Dziś wiem, że nie był to przypadek"33.

Kontynuując podjętą w książce myśl podczas homilii wygłoszonej z okazji ekumenicznego wspomnienia świadków wiary XX wieku, 7 maja 2000 roku w Koloseum papież mówił: „Doświadczenia drugiej wojny światowej i lat następnych nauczyły mnie patrzeć z uwagą i wdzięcznością na świetlany przykład tych, którzy od pierwszych lat XX wieku aż do jego końca doznawali prześladowań, przemocy i śmierci z powodu swej wiary i postępowania zgodnego z Chrystusową prawdą" 34 .

Wynosząc do chwały ołtarzy męczenników nazizmu, Jan Paweł II chciał ukazać światu, który patrzył na niego jako „żywego” świadka II wojny światowej „licznych znanych i nieznanych świadków, którzy w godzinie próby umieli z odwagą wyznawać otwarcie swą wiarę, sprzeciwiać się ateistycznej samowoli, i którzy nie ugięli się przed przemocą" ${ }^{35}$.

\subsection{Męczennicy komunizmu}

Totalitarny system komunistyczny w sposób szczególny wymierzył okrucieństwo swoich prześladowań przeciw Bogu i całym narodom. Ateistyczna ideologia dotknęła również Kościół. W wyniku prześladowań komunistycznych przyjął on postać ruin i zgliszcz we wszystkich wymiarach swojej egzystencji: od dewastacji materialnej, wyrażającej się w konfiskacie oraz ruinie budynków sakralnych, po uciemiężenie intelektualne, moralne oraz fizyczne duchowieństwa, osób zakonnych i świeckich ${ }^{36}$. Walka reżimu komunistycz-

\footnotetext{
33 Jan Paweł II, Dar i tajemnica, Kraków 1996, s. 36.

34 Tenże, Nigdy nie ugięli się przed moca zła. Homilia wygłoszona w Rzymie, 07.05.2000, „L'Osservatore Romano” (wyd. pol.) 21 (2000) 7-8, s. 33.

35 TM 6.

36 Zob. S. Nagy, Świadectwo Kościoła doświadczonego przemoca systemu komunistycznego, [w:] Świadectwo Kościoła katolickiego w systemie totalitarnym Europy Środkowo-Wschodniej, red. J. Nagórny i in., Lublin 1994, s. 30; por. także J. Misiurek, Wieki męczeństwa, [w:] Tertio millennio adveniente. U progu trzeciego tysiąclecia, red. G. Witaszek, Lublin 2000,
} s. 176. 
nego z religią polegała na zwalczaniu ludzi świeckich, którzy wierzyli w Boga i praktykowali, oraz na bezpośredniej eksterminacji duchowieństwa ${ }^{37}$.

Jan Paweł II należał do grona świadków prześladowań komunistycznych Kościoła, którzy widzieli, jak „[...] dokonywały się prześladowania wszystkich osób niewygodnych dla ustroju”38, między innymi „[...] przedstawicieli inteligencji, którzy nie podzielali światopoglądu marksistowskiego" ${ }^{39}$. Dlatego papież postarał się, by to właśnie za jego pontyfikatu Kościół katolicki w sposób uroczysty docenił świadków reżimu komunistycznego, publicznie uznając niektórych z nich godnych chwały ołtarzy.

Beatyfikacje męczenników z okresu prześladowań komunistycznych obejmują drugą połowę pontyfikatu Jana Pawła II. Papież osobiście przewodniczył 6 uroczystościom beatyfikacyjnym, podczas których ogłosił błogosławionymi 27 męczenników będących ofiarami reżimu komunistycznego ${ }^{40}$. W gronie tych błogosławionych byli męczennicy komunizmu z: Bułgarii, Chorwacji, Ukrainy, Słowacji oraz Białorusi.

Wynosząc do chwały ołtarzy męczenników komunizmu, Jan Paweł II pragnął zwrócić uwagę całego Kościoła na ich niezłomną postawę. Papież ukazywał ofiary komunistycznych prześladowań jako symbol zwycięstwa Kościoła nad niesprawiedliwością oraz przemocą systemu komunistycznego. Doceniał również to, że dzięki ich męczeńskim świadectwom wśród wiernych mieszkających w krajach uciskanych przez komunizm wiara przetrwała aż do dzisiaj.

\section{Męczennicy indywidualni}

Do grona męczenników indywidualnych zaliczyć należy kilkadziesiąt osób, które Jan Paweł II beatyfikował oraz kanonizował podczas swojego

37 Zob. R. Dzwonkowski, Męczeństwo w totalitarnym systemie sowieckim, „Znak” $52(2000) 540$, s. 74.

38 Jan Paweł II, Pamięć i tożsamość, Kraków 2005, s. 19.

39 Tamże, s. 19-20.

40 Zob. Ufficio delle celebrazioni liturgiche del sommo pontefice. Beatificazioni del santo Padre Giovanni Paolo II, art. cyt.; zob. także Z. Podlejski, Sól ziemi i świattość świata, t. 7, dz. cyt., s. 233-271. 20.12.2004 w obecności Jana Pawła II promulgowane zostały 22 dekrety Kongregacji Spraw Kanonizacyjnych. Jeden z nich dotyczył Władysława Findysza, diecezjalnego kapłana z Polski, męczennika komunizmu. Został on beatyfikowany po śmierci Jana Pawła II, 19.06.2005 w Warszawie. Zob. Dekrety w sprawach kanonizacyjnych, http://www. opoka.org.pl/biblioteka/W/WR/kongregacje/kswietych/dekrety_20122004.html [29.1.2015]. 
pontyfikatu. Chodzi przede wszystkim o tak zwanych „męczenników sumienia”. W odróżnieniu od grupowych męczenników, prześladowanych przez system państwa, w którym wiara niszczona była w sposób zorganizowany, indywidualni męczennicy ginęli z rąk pojedynczych prześladowców.

Na pierwszym miejscu wśród indywidualnych męczenników umieścić należy 6 męczennic czystości. Za pontyfikatu Jana Pawła II została kanonizowana Augustyna Liwia Pietrantoni ze Zgromadzenia Sióstr Miłosierdzia św. Joanny Antidy Thouret. Beatyfikowane zostały natomiast: siostra Anwarite Nengapeta ze Zgromadzenia Najświętszej Rodziny, Karolina Kózkówna, Pierina Morosini, Antonia Mesina oraz Teresa Bracco ${ }^{41}$.

Męczennikiem sumienia, który do końca pozostał wierny zasadom życia religijnego, jest błogosławiony Izydor Bakanja. Poniósł on śmierć męczeńską za to, że nie chciał zdjąć z szyi szkaplerza świętego ${ }^{42}$.

Wśród indywidualnych męczenników są również święci salezjanie: Alojzy Versiglia i Kalikst Caravario. Zostali oni umęczeni, ponieważ „bronili za cenę własnej krwi godności młodych kobiet, gdy te były w niebezpieczeństwie dostania się w ręce mężczyzn, nie respektujących ślubu czystości”" ${ }^{33}$.

Do grona indywidualnych męczenników należy także błogosławiona Marianna Biernacka. Przelała ona krew zarówno w celu uratowania swojego wnuka, który jeszcze się nie narodził, jak też matki dziecka, której życie znajdowało się w niebezpieczeństwie ${ }^{44}$.

Święta Edyta Stein zginęła natomiast za to, że była Żydówką, a błogosławione Marta Wołowska i Ewa Noiszewska, niepokalanki, zostały umęczone, ponieważ ukrywały Żydów w swoim klasztorze ${ }^{45}$.

${ }^{41}$ Zob. Ufficio delle celebrazioni liturgiche del sommo pontefice. Beatificazioni del santo Padre Giovanni Paolo II, art. cyt.; zob. także Ufficio delle celebrazioni liturgiche del sommo pontefice. Canonizzazioni del santo Padre Giovanni Paolo II, art. cyt.

42 Zob. Błogosławiony Izydor Bakanja, męczennik, http://www.brewiarz.pl/czytelnia/ swieci/08-12c.php3 [31.1.2015].

43 Jan Paweł II, Il sangue dei dui missionari martiri costituisce le fondamenta della Chiesa cinese. Homilia wygłoszona w Rzymie, 15.05.1983, „Insegnamenti di Giovanni Paolo II” t. 6/1, s. 1245.

44 Zob. Błogosławiona teściowa, http://www.opoka.org.pl/biblioteka/T/TS/swieci/echo2012-27_biernack a.html [31.1.2015].

45 Zob. L. Misiarczyk, Święta Edyta Stein - rozum zdobyty przez krzyż, http://mate usz.pl/czytelnia/lm-rozum-przez-krzyz.htm [31.1.2015]; zob. także A. Petrowa-Wasilewicz, Uratowały co najmniej 700 Żydów, http://ww w.niedziela.pl/artykul/4595/Uratowaly-conajmniej-700-Zydow [31.1.2015]. 
Jan Paweł II starał się ukazywać indywidualnych męczenników jako żywych świadków, których przesłanie pozostaje wciąż aktualne dla świata jako przykład „świadomej, ludzkiej i chrześcijańskiej godności osoby”46.

Podczas licznych uroczystości beatyfikacyjnych i kanonizacyjnych Jan Paweł II obdarzył Kościół i świat męczennikami, którzy przelaną krwią i ofiarą życia zaświadczyli o tym, że miłość do Boga, Kościoła i ludzi jest potężniejsza od śmierci. Doktryna Jana Pawła II na temat męczeństwa i męczenników, wygłoszona podczas beatyfikacji i kanonizacji, jest ciągle aktualna. Bowiem spośród wielu męczenników, których papież wyniósł do chwały ołtarzy, każdy chrześcijanin może znaleźć dla siebie jednego lub kilku świadków, będących przykładem i wzorem na drodze wiary. Bogate $\mathrm{w}$ treść papieskie nauczanie na temat męczeństwa i męczenników domaga się również nieustannego zgłębiania i badań.

46 Jan Paweł II, Marcel Callo, Pierina Morosini i Antonia Mesina - troje świeckich męczenników. Homilia wygłoszona w Rzymie, 04.10.1987, „L'Osservatore Romano” (wyd. pol.) 8 (1987) 9-10, s. 6. 